\title{
THE ECOSYSTEM SERVICES OF MANGROVES FOR SUSTAINABLE COASTAL AREA AND MARINE FAUNA IN LOMBOK, INDONESIA: A REVIEW
}

\author{
Pahmi Husain $^{1 *}$, Agil Al Idrus², and Muhammad Shohibul Ihsan³ \\ ${ }^{1}$ Devision of Environmental Science, School of Industrial Technology Universiti Sains Malaysia, Malaysia \\ ${ }^{2}$ Biology Education Study Program, Faculty of Teacher Training and Education, Universitas Mataram, Indonesia \\ ${ }^{3}$ Biology Study Program, Faculty of Mathematics and Science, Universitas Nahdlatul Wathan Mataram, Indonesia \\ *Email: pahmi.husain@student.usm.my
}

Diterima: 2 Januari 2020. Disetujui: 10 Februari 2020. Dipublikasikan: 30 April 2020

\begin{abstract}
Mangroves are one of the coastal ecosystems with high productivity, and their associated biodiversity provides a range of ecosystem services. The aerial roots of mangroves partly stabilize this environment and give a substratum on which many species of plants and animals live. Above the water, the mangrove trees and canopy provide important habitat for a wide range of species. These include birds, insects, mammals, and reptiles. Below the water, the mangrove roots are overgrown by epibionts such as tunicates, sponges, algae, and bivalves. The soft substratum in the mangroves forms a habitat for various infaunal and epifaunal species. At the same time, the space between roots provides shelter and food for motile fauna, such as prawns, crabs, and fishes. Mangrove litter is transformed into detritus, which partly supports the mangrove food web. Plankton, epiphytic algae, and microphytobenthos also form an essential basis for the mangrove food web. Due to the high abundance of food and shelter, and low predation pressure, mangroves form an ideal habitat for a variety of animal species, during part or all of their life cycles. As such, mangroves may function as nursery habitats for (commercially important) crab, prawn and fish species, and support offshore fish populations and fisheries.
\end{abstract}

Keywords: Mangrove ecosystem, ecosystem services, habitat, Lombok

\section{INTRODUCTION}

Mangroves are one of the coastal ecosystems with high productivity, and their associated biodiversity provide a range of ecosystem services (ES) including provisioning services (e.g., food, fuel, and honey), regulating services (e.g., storm protection, erosion control, and climate regulation), cultural services (e.g., spiritual enrichment, recreation, and aesthetic features) and supporting services (e.g., nutrient cycling, primary production) $[1,2,3,4]$. As such, mangrove roots become home to terrestrial as well as marine plants, algae, invertebrates, and vertebrates. Mangroves also provide both animals (e.g., fish, mollusks, crustaceans) and vegetable resources (e.g., medicinal plants, timber) to humans $[5,6]$.

Mangroves form a habitat for a wide variety of species. They are productive habitats and may support coastal fisheries for prawns and fishes [7]. Mangrove's ecosystem has an ecological function due to contribute as a place for local people to get their daily needs [8]. Vegetation of mangroves along the shoreline brings a larger benefits including coastal protection (e.g., coastal erosion control and wave attenuation), water filtration, carbon sequestration, recreation, education and benefits $[9,10,11]$. However, many mangrove forests are disappearing or are in danger of disappearing mainly due to rapid land-use change and environmental degradation $[11,12]$.

The degradation and loss of mangroves globally have raised the concerns of ecologists and economists [13, 14,15]. The degradation happened can be human-induced; for example, mangroves have been converted for shrimp production in Asian countries $[16,17]$. This degradation has led to habitat loss and a deterioration in the regulatory functions of mangroves, thereby reducing marine productivity and increasing coastal vulnerability to natural disasters $[13,18,19]$. The reduction of ecosystem capacity to provide ES could in turn, affect local livelihoods, more so in developing countries, where most of the population depends on natural resources for their livelihood $[17,20]$.

Regarding the mangrove services for animal habitats, many organisms from a variety of species within mangrove environments experienced vulnerable or threatened as a result of human activities in the coastal zone. Determining the value of mangroves and other estuarine habitats requires knowledge of their life history, physiology, and ecology. The evidence recommends that mangroves are essential to many species in the coastal zone, but a few of research is a significant impediment to an 
evaluation of their mangrove dependency. Estuarine habitats have been recognized as essential drivers of nearshore fish productivity. Worldwide, about $30 \%$ of all commercial fish species are mangrove-dependent [21].

Lombok Island has a potential mangrove ecosystem that supports the coastal area. The prospective area comprises Gili Sulat in East Lombok, Tanjung Luar, Lungkak, Kedome, Ekas Bay, and Jor Bay in the Southern Coastal part of Lombok Island $[8,22]$. Some ecosystem mangroves are transformed into ecotourism and education purposes [23,24]. But most of the mangrove ecosystems provide significant benefits for the local community and also for the sake of animal habitat within the coastal zone. However, the mangroves ecosystem should be maintained due to sustainable ecological and economic purposes for the future generation.

The current review summarises o ecosystem that services of mangroves due to preserving the habitat for terrestrial and marine fauna, and the importance of litter in the mangrove food web. We focus on the main groups of animals found in the mangrove habitat: various groups of macrofauna (epifauna and infauna), prawns, insects, fishes (bony fishes), amphibians, reptiles, and birds, accepting that a review of the complete fauna would be too farreaching for this particular issue and that some mangrove fauna are not discussed here.

\section{ABSORBENT LITERATURE \\ Mangroves as habitats for macrofauna}

Mangroves are inhabited by a variety of benthic invertebrates, such as brachyuran crabs, gastropods, bivalves, hermit crabs, barnacles, sponges, tunicates, polychaetes, and sipunculids. Mangrove invertebrates often show marked zonation patterns and colonize a variety of specific microenvironments. While some species dwell on the sediment surface or reside in burrows, others live on pneumatophores and lower tree trunks or prop-roots, burrow in decaying wood, or can even be found in the tree canopies [25].

Macrobenthos may be operationally separated into two groups, i.e., epifauna and infauna. Epifauna refers to those invertebrates that live on various substrates such as lower tree trunks and the sediment surface, but which do not burrow in it. A range of gastropods, crabs, and bivalve species are typical representatives of epifauna. Infauna refers to burrowing invertebrates that live within the sediment and includes crabs, pistol prawns, polychaetes, and sipunculids. The distinction between infauna and epifauna is not always straightforward, however, and not always related to the organisms' functional role. For example, while many sesarmid crabs create extensive burrow systems, others appear to find refuge in crevices from decaying wood or root structures, or their burrowing status is unknown [26].

Gastropods are typically one of the dominant and most conspicuous macrofauna in mangrove systems and occupy a wide range of ecological niches $[27,28]$. The distribution of gastropod species within a mangrove forest is influenced by a variety of factors such as light (as a significant factor determining algal growth and as a factor influencing humidity), tidal exposure, salinity, and substrate type.

Bivalves are often considered to be confined to a narrow seaward zone due to feeding and larval settlement restrictions [28]. In Southeast Asia, however, Polymesoda erosa is adapted for a semiterrestrial existence by living on the high shore where only occasional high tides inundate the habitat [29]. A number of bivalves with chemo-symbiotic associations have also been reported from mangroves [30].

In summary, benthic invertebrates in mangrove forests play an important ecological role by their activities of burrowing in the sediment where they assist in flushing toxic substances and modifying the oxidation status of the surrounding sediment. Feeding on plant matter (detritivory) assists in recycling organic matter and produces animal biomass, which is a source of food for vertebrate predators (e.g., reptiles, birds, and otters) and inshore fishes that come in with the high tide.

\section{Mangroves as habitats for prawns}

Prawns can only gain access to intertidal mangrove forests for $10-12 \mathrm{~h}$ each day when they are inundated by the tide. When the tide recedes, the prawns move out, and in the case of Penaeus merguiensis and $P$. indicus, aggregate close to the water's edge [31]. Mangrove forest can become a habitat for prawns. The good ecosystem mangroves will be produces much more prawns and also it can be taken by the local communities for consuming purpose who live along the shoreline.

\section{Mangroves as habitats for insects}

Mangroves provide a habitat that supports a large number of insects at different trophic levels. The primary trophic groups are (1) herbivorous insects that feed on leaves and other plant parts, (2) saproxylic and saprophagous insects that feed on dead and decaying 
organic matter, and (3) parasitic and predatory insect that feed or prey on other animals [32]

Insects that feed on dead trees or wood (saproxylic insects) or decaying organic material (saprophagous insects) play an important role in nutrient cycling in forests. Termites and wood-borers (usually the larvae of beetles or moths) form the majority of saproxylic insects, and a relatively characteristic assemblage occurs in mangroves. The relative abundance of a limited number of tree species provides an abundant and stable food source for this group of insects. In the intertidal zone, periodic or continuous flooding makes mangroves uninhabitable for many termite species that forage from the ground. However, species that nest above the ground thrive in this habitat in the absence of competing for fauna and in the presence of abundant food resources. Among these are drywood termites such as Glyptotermes, Neotermes and Cryptotermes, which feed on dead branches that die in the canopy, or on dead standing trees $[33,34]$.

A wide range of predatory and parasitic insects with a great diversity of host and habit occur in mangrove habitats. These include predatory larvae and adult insects that prey on other organisms, parasitoids that feed within a single host and eventually kill it, hyperparasitoids that parasitize parasitoids, and blood-sucking parasites of vertebrates. They occur throughout the mangroves, from the soil to the water surface and on mangrove plants, where they exert a restraining influence on populations of herbivorous and saprophagous organisms. Ants (Formicidae) are important predators in mangroves. One species of the weaver ant, Oecophylla smaragdina, that is common in mangroves in Australasia, nests by drawing the leaves of mangrove plants together with silk threads spun by their larvae. The ant has been shown to significantly reduce herbivory levels on the mangrove tree Rhizophora mucronata in Thailand [35] and the presence of this ant's pheromones on leaves of $R$. mucronata have been shown to deter feeding by the leaf beetle, Rhyparida wallacei [36].

\section{Mangroves as habitats for bony fishes}

Examples of species that occur in most mangrove areas of this region include the sly bream Acanthopagrus berda, the glassfish Ambassis gymnocephalus, the trevally Caranx sexfasciatus, the wolf herring Chirocentrus dorab, the tenpounder Elops machnata, the pursemouth Gerres filamentosus, the ponyfish Leiognathus equulus, the mangrove jack Lutjanus argentimaculatus, the flathead
Platycephalus indicus, the flounder Pseudorhombus arsius, the whiting Sillago sihama and the thornfish Terapon jarbua. A special group of fish species found in mangroves are the mudskippers (family Periophthalmidae) which occupy a specialised niche in the intertidal zone. They are physiologically and morphologically adapted to an amphibious existence in this zone with highly variable environmental conditions [37] and they are able to dwell on exposed mudflats when other fish species are forced to retreat to deeper waters with outgoing tides.

\section{The role of litter in the mangrove food web}

The idea that mangroves provide a trophic link with the abundant faunal communities within the mangrove ecosystem and in adjacent habitats has been a longstanding issue [38]. In the literature and was first proposed by the classical work of Odum and Heald (1972) in their 'outwelling hypothesis'. Odum and Heald suggested that the high productivity of mangroves is partially exported to the aquatic environment, providing an important food source for secondary consumers and thereby supporting adjacent fisheries. Relationships between fisheries or shrimp catch and the presence or extent of nearby mangroves are therefore unlikely to result from a direct trophic link, but rather from the effects of other factors such as the provision of a suitable nursery habitat, refuge from predators, or the provision of other food sources besides mangrove litter. The contribution of mangrove-derived organic matter in adjacent systems also appears to vary according to the environmental setting and geomorphology of the system, being more important in riverine/estuarine systems than in lagoon or island settings [39].

\section{Mangroves as drivers of nearshore fishery production}

The most direct approach to search for links between mangroves and fisheries is to use fish catch data in comparison with mangrove or estuarine parameters, [7] found a significant influence of mangrove forest characteristics (e.g., perimeter and area) on mangrove-related and estuarine fishery species, while latitude was the only variable influencing catch of offshore species along the northeastern Australian coast.

A review of literature demonstrated the dependence of fish harvests on estuarine environments, and showed the importance of these systems in terms of sustainable management of the coastal resource [40]. Some identified and synthesised ecological and biophysical links of mangroves that 
sustain seafood production from an economic perspective $[41,42]$.

\section{Mangroves as habitats for amphibians and reptiles}

Several independent evolutionary lines of reptiles and amphibians have successfully colonised, and are variously dependent on, mangrove ecosystems. These include frogs, marine and freshwater turtles, crocodilians, lizards, and marine and terrestrial snakes [32].

Globally, little is known of the amphibian fauna inhabiting mangroves [43]. Amphibians are generally intolerant of saline conditions found within mangroves, although many species are associated with estuarine habitats such as frog species from the genus Eleutherodactylus [44]. Notable exceptions include the crab-eating frog Rana cancrivora from Southeast Asia that is adapted to saltwater during all stages of its life cycle [45]. Turtles Freshwater turtles are known to inhabit estuaries, but little is known of their specific habitat requirements. The mangrove terrapin Batagur baska (from Central and Southeast Asia), and the painted terrapin Callagur borneoensis (from the Sundarbans, Bangladesh) are large freshwater chelonians that are known to inhabit tidal creeks and rivers [46].

Another reptile is Crocodilians. The relative importance of mangroves as a habitat for crocodilians, compared to other habitats, is variable, due to the wide diversity in their biology and ecology. However, as nurseries for fish and other marine animals on which crocodilians feed, mangroves provide an abundance of food sources at all life history stages. The estuarine crocodile Crocodylus porosus is one of the most notable species associated with mangroves. Generally, C. porosus do not nest in mangroves but are found nesting in vegetation fringing mangrove areas $[47,48]$.

\section{Mangroves as habitats for birds}

The insectivorous sunbird Anthreptes gabonicus which is found in mangroves but also in riverine woods hundreds kilometres in land in NorthWestern Australia, 16 of 104 species are more or less confined to mangroves. In Eastern Australia, 9 of 106, just 11 species are mangrove-dependent there, namely great-billed heron Ardea sumatrana, striated heron Butorides striata, chestnutrail Eulabeornis castaneoventris, collared kingfisher Todiramphus chloris, mangrove robin Peneoenanthe pulverulenta, kimberley flycatcher Microeca flavigaster tormenti, white-breasted whistler Pachycephala lanioides, dusky gerygone Gerygone tenebrosa, yellow silvereye Zosterops lutea, red-headed myzomela Myzomela erythrocephala, and mangrove honeyeater Lichenostomus fasciogularis [49].

The species origins of the birds in mangroves of Peninsular Malaysia has been analysed, where inland forests once abutted with mangrove trees over long stretches of the coast until well into the 20th century. Around one-third of the avian mangrove community (mainly kingfishers, sunbirds, warblers and woodpeckers) is shared with its former inland forest habitats, which may indicate how marginal mangroves were for at least some of the inland forest species that used their back zone. Leafbirds, broadbills, giant woodpeckers, and others formerly reported in the mangroves are now scarce or absent [50].

\section{Mangroves as an ecotourism services in Lombok}

One of the potential mangrove ecosystem that is being developed to become an ecotourism place is Gili Sulat. The richness of mangrove species on Gili Sulat is quite high, consisting of 11 species and diversity of fauna species, including: from insect species, namely Ants (Oecophylla sp.), Moths (Attacus sp.), Fleas (Dysdercus sp.); Species of crustaceans such as lobster mud. (Thalassina sp.), Spider species (Argipe spp., Nephila spp., Cryptophora spp.); Species of Blodok fish (Periopthalmodon sp.), Chopstick fish (Toxotes sp.), Species of reptiles such as lizards (Varanus sp.), tree snakes (Chrysopelea sp.), water snakes (Cerberus sp.); mammal species such as otters (Lutrogale sp.) and squirrels (Callosciurus sp.), primates (Nasalis larvatus) and many more such as mosquitoes, caterpillars, beaver (Lutrogale sp.) and squirrels (Callosciurus sp.), primates (Nasalis larvatus) and many more such as mosquitoes, caterpillars, bees (Lutrogale sp.) and squirrels (Callosciurus sp.) honey, bats and others [22].

Ecotourism is a new form of nonconsumptive, educational, and romantic tourism to relatively undisturbed and under-visited areas of immense natural beauty, and cultural and historical importance for the purposes of understanding and appreciating the natural and sociocultural history of the host destination [51]. Furthermore, the involvement of the local community is noteworthy to implement sustainable mangrove management practices within the ecotourism development in the mangrove ecosystem. By carrying the mangrove ecotourism, could mangrove maintain the durable form of land use, to contributing the environmental protection and providing socio-economic benefits to the local people through indirect values of the natural resources 


\section{CONCLUSION}

The ecosystem of mangroves has an ecological function. Mangroves form a habitat for a wide variety of species. The ecosystem of mangroves leads to becoming the productive habitats. It may support coastal fisheries for prawns and fishes due to contribute as a place for local people to get their daily needs. Other new services for human well-being to transform the function of mangrove ecosystem into the form of environmental services such as ecotourism and education. In this case, the combination of the use of mangroves from products of goods and services is a utilization strategy to achieve the goals of mangrove conservation and diversification of the livelihoods of local communities.

\section{REFERENCES}

[1] Millennium Ecosystem Assessment. 2005. Ecosystems and Human Well-being: Wetlands and Water Synthesis. World Resources Institute, Washington, DC.

[2] Millennium Ecosystem Assessment. 2005. Ecosystems and Human Well-being: Synthesis. Island Press, Washington, DC.

[3] TEEB. 2010. The Economics of Ecosystems and Biodiversity: Mainstreaming the economics of Nature: A synthesis of the approach, conclusions and recommendations of TEEB, Environment. TEEB.

[4] Pour, M.D., Motiee, N., Barati, A.A., Taheri, F., Azadi, H., Gebrehiwot, K., Lebailly, P. Van Passel, S., Witlox, F., (2017). Impacts of the hara biosphere reserve on livelihood and welfare in Persian gulf. Ecol. Econ. 141, 7686.

[5] Alves, R.R.N., Nishida, A.K., (2002). Aecdise do caranguejo- uçá, Ucides cordatus L. (Decapoda, Brachyura) na visão dos caranguejeiros. Interciencia 27, 110-117.

[6] Alves, R., Nishida, A., Hernandez, M., (2005). Environmental perception of gatherers of the crab 'caranguejo-uca' (Ucides cordatus, Decapoda, Brachyura) affecting their collection attitudes. J. Ethnobiol. Ethnomed. 1, 1024.

[7] Manson, F.J., Loneragan, N.R., Skilleter, G.A., Phinn, S.R., (2005). An evaluation of the evidence for linkages between mangroves and fisheries: a synthesis of the literature and identification of research directions. Oceanogr. Mar. Biol. Annu. Rev. 43, 483-513.

[8] Idrus, A. Al, Syukur, A., \& Zulkifli, L. (2019). The livelihoods of local communities : Evidence success of mangrove conservation on the coastal of East Lombok Indonesia The Livelihoods of Local Communities : Evidence Success of Mangrove Conservation on the
Coastal of East Lombok Indonesia. AIP Conference Proceedings 2199, 050010 (2019), 1-7.

[9] Barbier, E.B., (2016). The protective service of mangrove ecosystems: a review of valuation methods. Mar. Pollut. Bull. 109, 676-681.

[10] Kuenzer, C., Bluemel, A., Gebhardt, S., T.V., Dech, S., (2011). Remote sensing of mangrove ecosystems: a review. Rem. Sem. 3, 278.

[11] Vo, T. Quoc, Kuenzer, C., Oppelt, N., (2015). How remote sensing supports mangrove services valuation: A case study in $\mathrm{Ca} \mathrm{Mau}$ provinces, Vietnam. Ecosys. Serv. 14, 67-75.

[12] Giri, C., Pengra, B., Zhu, Z., Singh, A., Tieszen, L.L., (2007). Monitoring mangrove forest dynamics of the Sundarbans in Bangladesh and India using multi-temporal satellite data from 1973 to 2000. Estuar. Coast Shelf Sci. 73, 91-100

[13] Barbier, E.B., Hacker, S.D., Kennedy, C., Kock, E.W., Stier, A.C., Sillman, B.R., (2011). The value of estuarine and coastal ecosystem services. Ecol. Monogr. 81, 169-193.

[14] Barbier, E.B., Koch, E.W., Silliman, B.R., Hacker, S.D., Wolanski, E., Primavera, J., Granek, E.F., Polasky, S., Aswani, S., Cramer, L.A., Stoms, D.M., Kennedy, C.J., Bael, D., Kappel, C.V., Perillo, G.M.E., Reed, D.J., (2008). Coastal ecosystem-based management with nonlinear ecological functions and values - supporting material. Science 319, 321-323.

[15] Himes-Cornell, A., Pendleton, L., Atiyah, P., (2018). Valuing ecosystem services from blue forests: a systematic review of the valuation of salt marshes, sea grass beds and mangrove forests. Ecosyst. Serv. 30, 36-48.

[16] Barbier, E., Cox, M., (2003). Does economic development lead to mangrove loss? A cross country analysis. Contemp. Econ. Policy 21, 418-432.

[17] Brander, L.M., Wagtendonk, J., Hussain, A.S., McVittie, A., Verburg, P.H., de Groot, R.S., van der Ploeg, S., (2012). Ecosystem service values for mangroves in Southeast Asia: a meta-analysis and value transfer application. Ecosyst. Serv. 1, 62-69.

[18] Alongi, D.M., (2008). Mangrove forests: resilience, protection from tsunamis, and responses to global climate change. Estuar. Coast. Shelf Sci. 76, 1-13.

[19] Bosire, J.O., Kaino, J.J., Olagoke, A.O., Mwihaki, L.M., Ogendi, G.M., Kairo, J.G., Berger, U., Macharia, D., (2014). Mangroves in peril: unprecedented degradation rates of periurban mangroves in Kenya. Biogeosciences 11, 2623-2634.

[20] Owuor, M.A., Icely, J., Newton, A., Nyunja, J., Otieno, P., Tuda, A.O., Oduor, N., (2017). Mapping of ecosystem services flow in Mida Creek, Kenya. Ocean Coast. Manage. 140, 1121. 
[21] Naylor, R.L., Goldburg, R.J., Primavera, J.H., Kautsky, N., Beveridge, M.C.M., Clay, J., Folke, C., Lubchenco, J., Moony, H., Troell, M., (2000). Effect of aquaculture on world fish supplies. Nature 405, 1017-1024.

[22] Idrus A, Al. 2014. Mangrove Gili Sulat Lombok Timur. Arga Puji Press. Mataram, Lombok Indonesia. pp 216.

[23] Idrus, A. A1., Syukur, A., \& Zulkifli, L. 2018. Konservasi Mangrove Berbasis Institusi Masyarakat Lokal Untuk Mendukung Pengembangan Ekowisata Dan Sumber Belajar Biologi di Pantai Selatan Lombok Timur.

[24] Idrus, A. Al., Syukur, A., \& Zulkifli, L. 2018. Sosialisasi Peran dan Fungsi Mangrove Pada Masyarakat di Kawasan Gili Sulat Lombok Timur.

[25] Ashton, E.C., (1999). Biodiversity and community ecology of mangrove plants, molluscs and crustaceans in two mangrove forests in Peninsular Malaysia in relation to management practices. Ph.D. Thesis. University of York, UK. Econ. 35, 47-61.

[26] Gillikin, D.P., Kamanu, C.P., (2005). Burrowing in the East African mangrove crab, Chiromantes ortmanni (Crosnier, 1965) (Decapoda, Bracayura, Sesar- midae). Crustaceana 78, 1273-1275.

[27] Cantera, J., Arnaud, P.M., Thomassin, B.A., (1983). Biogeographic and ecolo- gical remarks on molluscan distribution in mangrove biotopes. 1. Gastro- pods. J. Molluscan Stud. 49, 10-26.

[28] Plaziat, J.C., 1984. Mollusc distribution in the mangal. In: Por, F.D., Dor, I. (Eds.), Hydrobiology of the Mangal-The Ecosystem of the Mangrove Forests. Developments in Hydrobiology 20. Dr. W. Junk Publishers, The Hague, pp. 111-143.

[29] Morton, B.S., (1976). The biology and functional morphology of the Southeast Asian mangrove bivalve, Polymesoda (Gelonia) erosa (Solander 1786) (Bivalvia: Corbiculidae). Can. J. Zool. 54, 482-500.

[30] Lebata, M.J.H.L., Primavera, J.H., (2001). Gill structure, anatomy and habitat of Anodontia edulenta: evidence of endosymbiosis. $J$. Shellfish Res. 20, 1273-1278.

[31] Kenyon, R.A., Loneragan, N.R., Manson, F.J., Vance, D.J., Venables, W.N., (2004). Allopatric distribution of juvenile red-legged banana prawns (Penaeus indicus H. Milne Edwards, 1837) and juvenile white banana prawns (Penaeus merguiensis De Man, 1888), and inferred extensive migration, in the Joseph Bonaparte Gulf, northwest Australia. J. Exp. Mar. Biol. Ecol. 309, 79-108.

[32] Nagelkerken, I., Blaber, S. J. M., Bouillon, S., Green, P., Haywood, M., Kirton, L. G., Somerfield, P. J. (2008). The habitat function of mangroves for terrestrial and marine fauna : A review. 89, 155-185.

[33] Miller, L.R., Paton, R., 1983. Cryptotermes in mangroves in the Northern Territory (Isoptera: Kalotermitidae). J. Aust. Entomol. Soc. 22, 189-190.

[34] Salick, J., Tho, Y.P., (1984). An analysis of termite faunae in Malayan rainforests. J. Appl. Ecol. 21, 547-561.

[35] Offenberg, J., Havanon, S., Aksornkoae, S., Macintosh, D.J., Nielsen, M.G., (2004). Observations on the ecology ofweaver ants (Oecophylla smaragdina Fabricius) in a Thai mangrove ecosystem and their effect on herbivory of Rhizophora mucronata Lam. Biotropica 36, 344-351.

[36] Offenberg, J., Nielsen, M.G., Macintosh, D.J., Havanon, S., Aksornkoae, S., (2004). Evidence that insect herbivores are deterred by ant pheromones. Proc. Royal Soc. Lond. B. 271 (Biology Letters Suppl. 6), S433-S435.

[37] Clayton, D.A., (1993). Mudskippers. Mar. Biol. Oceanogr. Annu. Rev. 31, 507- 577.

[38] Odum, W.E., Heald, E.J., (1972). The detritusbased food web of an estuarine mangrove community. Bull. Mar. Sci. 22, 671-737.

[39] Pineda, J.E.M., 2003. The contribution of mangrove outwelling to coastal food webs as a function of environmental settings. Ph.D. Thesis. University of Louisiana at Lafayette, USA.

[40] Baran, E., Hambrey, J., (1998). Mangrove conservation and coastal management in southeast Asia: What impact on fishery resources? Mar. Poll. Bull. 37, 431-440.

[41] Ro"nnba"ck, P., (1999). The ecological basis for economic value of seafood production supported by mangrove ecosystems. Ecol. Econ. 29, 235-252.

[42] Barbier, E.B., 2000. Valuing the environment as input: review of applications to mangrovefishery linkages.

[43] Kathiresan, K., Bingham, B.L., (2001). Biology of mangroves and mangrove ecosystems. Adv. Mar. Biol. 40, 81-251.

[44] Hedges, S.B., Thomas, R., (1992). A new marsh-dwelling species of Eleuther- odactylus from Haiti (Anura: Leptodactylidae). $J$. Herpetol. 26, 191-195.

[45] Dunson, W.A., (1977). Tolerance of high temperature and salinity by tadpoles of the Philippine frog, Rana cancrivora. Copeia 1977, 375-378.

[46] Blanco, S., Behler, J.L., Kostel, F., (1991). Propogation of the Batagurine Turtles Batagur baska and Callagur borneoensis at the Bronx Zoo. In: Beaman, K.R., Caporaso, F., McKeown, S., Graff, M.D. (Eds.), Proceedings of the 1st International Symposium on Turtles and Tortoises: Conservation and Captive Husbandry. pp. 63-65. 
Jurnal Inovasi Pendidikan dan Sains

Vol. 01 No.01, April $2020: 1-7$

ISSN 2721-9119 (Online)

[47] Webb, G.J.W., Messel, H., Magnusson, W., (1977). The nesting of Crocodylus porosus in Arnhem Land, Northern Australia. Copeia 2, 238-249.

[48] Webb, G.J.W., Buckworth, R., Manolis, S.C., (1983). Crocodylus johnsoni in the McKinlay River, N.T. VI. Nesting biology. Aust. Wildl. Res. 10, 607-637.

[49] Ffrench, R.P., (1966). The utilization of mangroves by birds in Trinidad. Ibis 108, 423424.

[50] Wells, D.R., 1999. The Birds of the ThaiMalay Peninsula. Vol. 1, non- passerines, Academic Press, London.

[51] Sirakaya, E., Sasidharan, V., and Sönmez, S., (1999). Redefining Ecotourism: The Need for a Supply-Side View. Journal of Travel Research, 38, 168-172. 